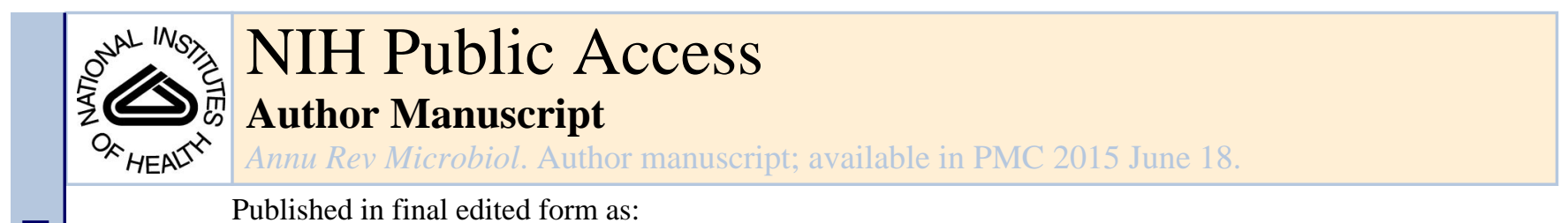

Published in final edited form as:

Annu Rev Microbiol. 2014 ; 68: 439-458. doi:10.1146/annurev-micro-092412-155711.

\title{
Subterfuge and Sabotage:
}

Evasion of Host Innate Defenses by Invasive Gram-Positive Bacterial Pathogens

Cheryl Y.M. Okumura ${ }^{1}$ and Victor Nizet $^{2}$

1'Department of Biology, Occidental College, Los Angeles, California 90041; okumura@oxy.edu

${ }^{2}$ Department of Pediatrics and Skaggs School of Pharmacy and Pharmaceutical Sciences, University of California, San Diego, La Jolla, California 92093; vnizet@ucsd.edu

\section{Abstract}

The development of a severe invasive bacterial infection in an otherwise healthy individual is one of the most striking and fascinating aspects of human medicine. A small cadre of gram-positive pathogens of the genera Streptococcus and Staphylococcus stand out for their unique invasive disease potential and sophisticated ability to counteract the multifaceted components of human innate defense. This review illustrates how these leading human disease agents evade host complement deposition and activation, impede phagocyte recruitment and activation, resist the microbicidal activities of host antimicrobial peptides and reactive oxygen species, escape neutrophil extracellular traps, and promote and accelerate phagocyte cell death through the action of pore-forming cytolysins. Understanding the molecular basis of bacterial innate immune resistance can open new avenues for therapeutic intervention geared to disabling specific virulence factors and resensitizing the pathogen to host innate immune clearance.

\section{Keywords}

Streptococcus pyogenes; Streptococcus agalactiae; Staphylococcus aureus; Streptococcus pnemoniae; innate immunity; immune evasion

\section{INTRODUCTION}

Our innate immune system comprises a highly integrated and effective network of cells and effector molecules, standing ready to broadly defend us against infection in a complex environment of continual microbial exposures. Its many layers include the physical barrier functions of skin and mucosal epithelium, niche competition and antimicrobial products produced by the normal microflora, and soluble antimicrobial effectors such as host defense peptides, complement proteins, or reactive oxygen species (ROS). Sophisticated mechanisms intrinsic to the innate immune system allow the host to recognize molecular patterns of microbial origin, leading to activation and targeting of inflammatory responses. Of critical importance, specialized leukocytes such as neutrophils and macrophages undertake directed migration, phagocytosis, and production of microbicidal compounds to efficiently clear bacterial pathogens that threaten to gain access to deeper tissues. 
Failures of innate immunity define the clinical field of infectious diseases. Often the cause is intrinsic to the human host, such as the developmental immaturity or senescence of immune functions at extremes of age; immunodeficiency due to genetic, acquired, or iatrogenic origin; breakdown in barrier integrity; high-risk behaviors or exposures; or general malnutrition or chronic illness. Yet in other cases, serious infection develops in previously healthy individuals, and physicians know to manage such patients by empirically targeting a short list of likely suspects. Among the most important human pathogens in this category are four coccoid-shaped, gram-positive bacterial species that consistently demonstrate the capacity to produce invasive and potentially life-threatening infections: Staphylococcus aureus, Streptococcus pneumoniae (SPN), group A Streptococcus (GAS), and group B Streptococcus (GBS). The unique pathogenic potential of these organisms is played against a background of normalcy: Each of these four bacteria colonizes the skin or mucosal surfaces of 10-30\% of healthy individuals without producing symptoms. S. aureus, SPN, and GAS are also associated with a variety of mild, superficial infections.

S. aureus is currently the leading cause of serious bacterial infections in the United States and many other developed countries, with an ability to produce abscesses in every tissue and organ system. In recent decades, marked increases in disease caused by multidrug (methicillin)-resistant $S$. aureus (MRSA) have occurred in both health care and community settings, posing an ominous threat to public health (120). However globally, the most lethal bacterial pathogen remains SPN, estimated to cause $\sim 10 \%$ of all deaths in children in the first 5 years of life (90). Invasive GAS infections produce a global burden estimated at more than 650,000 new cases and 160,000 deaths each year (17). Finally, GBS is the leading cause of bacterial pneumonia, sepsis, and meningitis in newborn infants in Europe, the Americas, and Australia, where universal maternal screening programs seek to guide intrapartum antibiotic prophylaxis (121). Among these invasive gram-positive pathogens, only SPN has a licensed preventive vaccine.

The propensity of $S$. aureus, SPN, GAS, and GBS to produce systemic infection in otherwise healthy individuals reveals a capacity of each pathogen to resist innate defense mechanisms that normally prevent microbial dissemination (Figure 1). Notably, in gaining access to the bloodstream and spreading to distant organs, the pathogen thwarts the sophisticated opsonophagocytic clearance function of neutrophils and macrophages. In this review, we examine the virulence mechanisms of these four invasive gram-positive pathogens to subvert the host phagocyte defense system, placing a special emphasis on recent discoveries validated through molecular genetic analysis, human tissue culture systems, and small animal models of infection.

\section{EVASION OF HOST COMPLEMENT DEPOSITION AND ACTIVATION}

The complement system, though complex in its pathways of activation, provides two key outcomes for host innate immunity: opsonizing bacteria for phagocytosis and direct bacterial killing by membrane perturbations mediated by the membrane attack complex (MAC) (104). Activation of the complement system converges upon the formation of $\mathrm{C} 3$ convertases, which deposit the opsonin $\mathrm{C} 3 \mathrm{~b}$ on the bacterial surface. C 3 conversion subsequently activates $\mathrm{C} 5$ convertases to generate $\mathrm{C} 5 \mathrm{a}$, a powerful chemoattractant for phagocytic cells, 
and $\mathrm{C} 5 \mathrm{~b}$, which initiates the formation of the MAC (Figure 1). Although the MAC of the complement system localizes to the surface of gram-positive bacteria, it seems to have little effect on bacterial viability (12), and molecular details of the activity and function of the MAC on gram-positive bacterial surfaces are not known. Thus, the most effective functions of the complement system against gram-positive pathogens are to opsonize the bacteria via $\mathrm{C} 3 \mathrm{~b}$ and recruit phagocytes to the site of infection via C5a (Figure 1).

Complement activation is tightly controlled by endogenous regulators to limit inflammatory injury to host tissues. Nearly all of the important gram-positive pathogens express molecules that acquire the host fluid-phase inhibitory complement regulators factor $\mathrm{H}(34,56,93)$ or C4b-binding protein (C4BP) $(2,38)$ on the bacterial surface, allowing these regulators to interact with C3 convertases and accelerate their decay (104). Although S. aureus does not bind factor $\mathrm{H}$ or $\mathrm{C} 4 \mathrm{BP}$, it secretes proteins that themselves act as complement inhibitors in an analogous manner (104). The secreted staphylococcal complement inhibitor potently inhibits C3 convertase to prevent C3 conversion, phagocytosis, and C5a formation (103), and extracellular fibrinogen-binding protein and extracellular complement-binding protein bind to the $\mathrm{C} 3 \mathrm{~b}$ molecule directly to impair $\mathrm{C} 3$ convertase function (60).

Still other mechanisms prevent C3b deposition on the bacterial surface. Some GAS M proteins and $S$. aureus clumping factor A bind fibrinogen, which acts as a molecular shield to prevent C3b deposition $(21,45)$. GBS capsule and SPN serotypes 2 and 4 capsules impair bacterial opsonization with $\mathrm{C} 3 \mathrm{~b}$ by both the alternative (83) and classical complement pathways (53). Finally, $S$. aureus clumping factor binds the host complement inhibitory protein factor I, which cleaves $\mathrm{C} 3 \mathrm{~b}$ into iC $3 \mathrm{~b}$ (45), preventing further amplification of the complement cascade and activation via the alternative pathway.

Gram-positive pathogens additionally employ several proteolytic strategies to dispose of complement system components. Both GAS and GBS possess specific proteases capable of cleaving C5a $(62,113)$. Additionally, gram-positive species also elaborate broader-spectrum proteases that aid in the degradation of complement system proteins. Notable among these is the cysteine protease SpeB of GAS (50), S. aureus serine protease V8 (61), and the $S$. aureus metalloprotease aureolysin (73), which degrade key complement system components, including the opsonin C3b and the chemoattractant C5a. Finally, GAS streptokinase (81) and SPN PepO protein (3) can acquire and activate host plasminogen to plasmin on the bacterial surface to accelerate C3b degradation. SPN PepO protein binds plasminogen, allowing activation by urokinase-type plasminogen activator and subsequent plasmin-mediated cleavage of $\mathrm{C} 3 \mathrm{~b}$ (3). Though active plasmin can also generate fibrin, the accumulation of fibrin further prevents $\mathrm{C} 3 \mathrm{~b}$ deposition $(21,45)$ and additionally aids grampositive bacteria in platelet-mediated adhesion to damaged endothelial surfaces (86a). Thus, gram-positive pathogens have evolved a repertoire of virulence factor proteins to combat the complement system. The redundancy of anti-complement factors and the multiple arms of the complement system that are targeted by these factors underscore the importance of complement defense for gram-positive bacteria to survive in blood and disseminate during invasive infection. Combating the complement defense strategies of gram-positive bacteria, while challenging, could prove to be a useful approach toward new drug therapies. 


\section{INHIBITION OF ANTIBODY-MEDIATED OPSONOPHAGOCYTOSIS}

The phagocytosis of bacteria by host neutrophils and macrophages is markedly enhanced upon binding of specific antibody to allow Fc receptor-mediated uptake. Antibody binding to the bacterial surface also activates the classical pathway of complement through $\mathrm{C} 1 \mathrm{q}$ binding to the $\mathrm{Fc}$ region of the immunoglobulin molecule. Pathogens can subvert antibody function through nonopsonic binding and antibody degradation.

One celebrated strategy by which gram-positive bacteria avoid recognition of antigen-bound immunoglobulins by both $\mathrm{Fc}$ receptors and $\mathrm{Clq}$ is to reorient the antibody molecule by binding to its $\mathrm{Fc}$ region, competitively inhibiting downstream Fc effector functions. Most notably, protein A, the most abundant protein on the surface of $S$. aureus, binds to the Fc gamma region of $\operatorname{IgG}$ to inhibit opsonophagocytic killing (67). M1 and protein $\mathrm{H}$ of GAS also bind immunoglobulin $\mathrm{Fc}$, but the affinity of these interactions tend to be lower than antibody-antigen affinities, such that this strategy may only be viable in low Ig concentration environments (89).

Bacterial cleavage of the Ig molecule can thwart antibody binding and recognition. Certain purified bacterial proteases exhibit direct antibody cleavage activity, such as the V8 protease of S. aureus (99) and the GAS cysteine proteases SpeB (30) and Mac1/IdeS (75). However, detailed mutational and biochemical studies under physiological conditions raise a question as to whether native expression of the latter two proteases is sufficient to impede opsonophagocytosis $(91,95)$. Gram-positive pathogens can also coopt the activity of a host protease plasminogen to acquire antibody-degrading capacity. Staphylokinase activates plasminogen to plasmin, which can then cleave surface-bound immunoglobulins as well as C3b (105). Other gram-positive bacteria possess plasminogen-activating proteases $(3,81$, $126,128)$; though it has not been directly demonstrated for these proteases, one would predict the resulting activated plasmin could similarly degrade host antibodies.

Even if antibody successfully binds its antigenic target on the Gram-positive bacterial surface in the correct orientation, the pathogens have evolved additional mechanisms to thwart Fc-mediated effector functions. S. aureus microbial surface components recognizing adhesive matrix molecule (MSCRAMMs) can bind C1q in a manner that renders $\mathrm{C} 1$ complexes inactive (63), and SPN can use C1q to adhere to host epithelial and endothelial cells (1), concomitantly preventing its interaction with other complement proteins. The secreted GAS enzyme EndoS hydrolyzes the N-linked glycan of the constant region of the $\operatorname{IgG}$ heavy chain and blocks the antibody's ability to interact with Fc receptors (111). Finally, the secreted $S$. aureus formyl peptide receptor-like 1 inhibitor (FLIPr) can bind Fc receptors on host phagocytes, thereby preventing their recognition of and binding to antigenbound antibody (115).

\section{RESISTANCE TO HOST OXIDATIVE BURST KILLING}

Phagocytosis of bacterial particles induces the oxidative burst response, a key host microbicidal process in which oxygen is consumed and toxic ROS are generated. This pathway is catalyzed by two major reactions in the cell. The first reaction begins with activation and translocation of the NADPH oxidase (NOX) complex to the phagosome, 
producing superoxide $\left(\mathrm{O}_{2}^{-}\right)$that quickly dismutates to hydrogen peroxide $\left(\mathrm{H}_{2} \mathrm{O}_{2}\right)$ (Figure 2). Both $\mathrm{O}_{2}{ }^{-}$and $\mathrm{H}_{2} \mathrm{O}_{2}$ can damage iron-sulfur clusters of dehydratases, releasing free iron (Fenton reaction), which when combined with $\mathrm{H}_{2} \mathrm{O}_{2}$ can generate hydroxyl radicals lethal to many bacteria (127). The second reaction involves the conversion of both $\mathrm{O}_{2}{ }^{-}$and $\mathrm{H}_{2} \mathrm{O}_{2}$ by the azurophilic granule enzyme myeloperoxidase (MPO), generating hypochlorite $(\mathrm{HOCl})$ (127). It is thought that of all the ROS produced $\mathrm{HOCl}$ exerts the most bacteridal activity (127).

To survive the oxidative burst response, gram-positive pathogens have mechanisms to either prevent the production of or dispose of harmful oxidants (129) (Figure 2). Invasive grampositive species encode a bacterial superoxide dismutase (SOD) $(65,130)$ that accelerates conversion of $\mathrm{O}_{2}^{-}$to $\mathrm{H}_{2} \mathrm{O}_{2}$. Bacteria must then further convert $\mathrm{H}_{2} \mathrm{O}_{2}$ to a less reactive molecule. Catalase is a common mechanism for gram-negative bacteria and $S$. aureus to oxidize $\mathrm{H}_{2} \mathrm{O}_{2}$ into molecular oxygen and water. However, all streptococci and even some strains of $S$. aureus are catalase-negative and must therefore deploy other systems to enzymatically remove $\mathrm{H}_{2} \mathrm{O}_{2}$ (129). Reducing pathways such as thioredoxin systems provide electrons to small molecules that can react with $\mathrm{H}_{2} \mathrm{O}_{2}(40,108)$, whereas the tripeptide glutathione can reduce $\mathrm{H}_{2} \mathrm{O}_{2}$ directly (55). GAS additionally produces its own iron-binding protein (118), whereas $S$. aureus expression of bacterial nitric oxide (NO) synthase generates NO (44), both of which inhibit Fenton chemistry. The enzyme alkylhydroperoxidase can convert $\mathrm{H}_{2} \mathrm{O}_{2}$ to alcohol and water and is another means for grampositive pathogens to eliminate $\mathrm{H}_{2} \mathrm{O}_{2}$ (129). Depletion of $\mathrm{H}_{2} \mathrm{O}_{2}$ thus reduces the opportunity for MPO to generate the more toxic $\mathrm{HOCl}$ species. Strategies to prevent $\mathrm{H}_{2} \mathrm{O}_{2}$ depletion may therefore improve infection outcomes. For example, the recent development of specific bacterial nitric oxide synthase (bNOS) inhibitors (48a) to counter $S$. aureus expression of bNOS that promotes ROS resistance (120a) opens up new antimicrobial possibilities.

In addition to the diverse enzymatic strategies to limit ROS generation, certain grampositive pathogens have evolved antioxidant shields to enhance their intrinsic resistance to oxidant-mediated damage. The eponymous golden carotenoid pigmentation of $S$. aureus, the result of cell wall-associated carotenoid pigments $4^{\prime}, 4^{\prime}$-diaponeurosporene and staphyloxanthin, provides broad-based free radical scavenging properties and the ability for quenching single oxygen (80), increasing neutrophil resistance. GBS similarly produces a carotenoid pigment known as Granadaene that aids in ROS neutralization and impedes phagocyte killing (79). Pigment production therefore represents an important drug target to render the bacteria more sensitive to the killing mechanisms of the host. Recently, the indole derivative 7-benzyloxyindole was shown to inhibit staphyloxanthin synthesis, rendering $S$. aureus colorless and sensitive to ROS killing (74a). This chemical had an added feature of also blocking the bacterium's expression of the toxin a-hemolysin (74a).

\section{RESISTANCE TO PHAGOCYTIC GRANULE COMPONENTS}

A critical element of bacterial killing within the phagocytic cell occurs when various intracellular granules fuse with the phagosome to deliver their cargoes of antimicrobial enzymes and peptides. Granule components include the cell wall-degrading enzyme lysozyme; serine proteases including cathepsin G, elastase, azurocidin, and proteinase 3; and 
small cationic antimicrobial peptides (AMPs), such as defensins and cathelicidin. Although the serine proteases have been demonstrated to have direct antimicrobial effects on grampositive pathogens (114), the main antibacterial function of these proteases may revolve around processing of AMPs from inactive precursors to their mature form.

Gram-positive bacterial surfaces consist of a thick, dense, and complex layer of proteins and carbohydrate structures including teichoic acids, peptidoglycan, and capsule (Figure 3). Lysozyme, a muramidase present in phagocytic cells' granules, cleaves peptidoglycan between $\beta$-1,4-linked $N$-acetyl glucosamine (GlcNAc) and $N$-acetyl muramic acid (MurNAc). Lysosome can kill bacteria through cell wall degradation, which further generates peptidoglycan (PPG) fragments that can be recognized by pattern-recognition receptors (PRRs, see sidebar) such as NOD2 (35) and peptidoglycan recognition protein (25). Gram-positive pathogens have evolved mechanisms to PPG less recognizable to lysozyme, including PPG modification in SPN (122) and GAS (41), $O$-acetylation in SPN (32) and $S$. aureus (11), and masking of PPG with covalently linked wall teichoic acid (WTA) structures in S. aureus (8). Functionally, modification of PPG to impart lysozyme resistance results in not only evasion of detection by PRRs, but also limiting of host production of important inflammatory mediators such as interleukin (IL)-1 $\beta$ via the Nod-like receptor (NLR) family pyrin-domain-containing 3 (NLRP3) inflammasome (see sidebar) and interferon- $\beta(64,109)$.

AMPs such as cathelicidin LL-37 are small cationic molecules that form pores in or otherwise destabilize the bacterial membrane. Surface charge and access to the bacterial membrane are important factors in determining the potency of endogenous AMPs. Grampositive bacteria achieve the first of these defenses by altering their surface charge, chiefly by biochemical modification of cell wall teichoic acids (Figure 3). Teichoic acids include both lipoteichoic acids (LTAs) and WTAs (14). All teichoic acids contain a negatively charged anionic backbone (14). Addition of $\mathrm{p}$-alanyl esters to teichoic acids through the activity of enzymes encoded by the dlt operon can reduce the net negative charge of teichoic acids; accordingly, bacteria lacking the genes involved in ${ }_{\mathrm{D}}$-alanylation are more susceptible to positively charged cationic AMPs such as human cathelicidin LL-37 and a-defensins (72, $96,97)$. There is also evidence to suggest that $\mathrm{D}$-alanylation prevents penetration and access of AMPs to the bacterial surface owing to increased surface density rather than charge (106). Alteration of teichoic acids with positively charged lysyl-phosphatidylglycerol also reduces AMP interaction with $S$. aureus (87).

Gram-positive bacteria, particularly GAS and S. aureus, also possess proteases that can cleave AMPs into nonfunctional breakdown products. S. aureus aureolysin (110) and the broad-spectrum cysteine protease SpeB of GAS (58) have been shown to cleave and inactivate human cathelicidin LL-37. GAS streptokinase can also activate plasmin on the GAS surface to degrade LL-37 (49), mirroring its protective action against C3b (81).

Another means of AMP resistance occurs through the expression of bacterial surface molecules that capture the host defense molecules, blocking them from reaching the cell membrane target of action. The hypervariable $\mathrm{N}$-terminal domain of GAS M1 protein was recently shown to bind and sequester LL-37, preventing access to the bacterial membrane 
(74). The secreted GAS streptococcal inhibitor of complement (SIC), originally described as preventing formation of the complement MAC complex, is also capable of binding LL-37 to prevent bacterial killing (94). The binding of human neutrophil a-defensins into a complex by $S$. aureus staphylokinase impedes their bactericidal activity (57), and GBS surface pilus protein PilB captures cathelicidin to increase pathogen resistance (82). Finally, although the precise mechanisms remain to be elucidated, GBS penicillin-binding protein-1a and GAS hyaluronic acid capsule both increase bacterial AMP resistance in manners independent of surface charge alteration $(29,59)$, perhaps again acting as a molecular shield.

\section{IMPEDING PHAGOCYTE RECRUITMENT AND ACTIVATION}

A perhaps even more elegant suite of immune evasion strategies by which these pathogens limit detection and diminish the effectiveness of host innate immune clearance is emerging: virulence factors that block phagocyte recruitment and phagocyte activation to reduce bacterial exposure to antimicrobial molecules.

In addition to degrading the complement-derived chemoattractant C5a (62), GAS produces the protease SpyCEP, which specifically targets the important neutrophil chemokine IL-8 (132), whereas GBS produces a similar serine protease (CspA), which cleaves the related CXC chemokines Gro- $\alpha$, Gro- $\beta$, and Gro- $\gamma$ (15). Alternatively, gram-positive pathogens can block neutrophil recruitment by antagonizing the chemoattractant receptors. Formylmethionyl-leucyl-phenylalanine (fMLP) peptides are powerful neutrophil chemoattractants that arise from bacterial protein degradation and can activate high-affinity fMLP peptide receptors on neutrophils in picomolar concentrations. Chemotaxis inhibitory protein of $S$. aureus (CHIPS) is secreted by the pathogen and binds specifically to the fMLP peptide (and C5a) receptors to impair their sensing function (104). Likewise, S. aureus releases FLIPr, another virulence factor capable of antagonizing the fMLP peptide receptor to impair leukocyte responses to the bacterial-derived chemoattractant agonists (98).

As a general rule, gram-positive bacteria are not sensed effectively by extracellular Toll-like receptors (TLRs), but intracellular detection is important (see sidebar). Phagocytosed grampositive pathogens have been shown to evade detection by limiting phagosome acidification or phagosome fusion with granules or lysosomes $(88,112)$ or by escaping the phagosome altogether, as mediated by toxins such as GAS SLO and S. aureus leukocidins $(37,92)$. Other mechanisms of evading intracellular killing include using protein mimicry to blunt immune signaling. S. aureus was recently shown to express a Toll/IL-1 receptor (TIR)domain-containing protein (TirS) that interferes with stimuli-induced TLR2-mediated NF$\kappa \mathrm{B}$ activation, c-Jun N-terminal kinase (JNK) phosphorylation, and secretion of proinflammatory cytokines (7). GAS DNase Sda1 can also cleave its own CpG-rich DNA, diminishing pathogen sensing and innate immune responses mediated by the intracellular sensor TLR-9 (119).

Molecular mimicry of host glycan structures by bacterial capsular polysaccharide capsules can promote innate immune evasion by gram-positive pathogens. The hyaluronic acid capsule of GAS is structurally identical to the nonsulfated glycosaminoglycans abundant in human skin and cartilage, thus covering the bacteria in a nonimmunogenic cloak that hides 
underlying opsonization targets. The terminal sialic acid residues in the capsule of GBS mimic common glycoepitopes on the surface of all mammalian cells and can engage Siabinding immunoglobulin-like lectins (Siglecs), leukocyte receptors with inhibitory signaling properties that regulate the baseline activation (19). Recent data show that upon Siglec engagement, leukocyte responses such as oxidative burst and cytokine release are blunted, promoting GBS survival and virulence (20,23). Furthermore, certain strains of GBS show the capacity to engage inhibitory Siglecs through their surface $\beta$-protein, once again limiting leukocyte activation (18). This demonstration of a sialic acid-independent mechanism of Siglec subversion suggests that other nonsialylated bacterial pathogens could evolve similar strategies for innate immune resistance.

\section{ESCAPE FROM NEUTROPHIL EXTRACELLULAR TRAPS}

Neutrophil extracellular traps (NETs) are a relatively recently appreciated aspect of innate immune defense in which neutrophils undergo a specialized cell death process at tissue foci of infection, whereon they release a highly decondensed chromatin structure containing histones, granule proteases, and AMPs $(5,123)$. Neutrophils produce NETs in response to gram-positive pathogens such as GAS and $S$. aureus (123) and are thought to kill microbes by exposing them to high local concentrations of antimicrobial effectors (5). The structure of NETs, held together by the DNA backbone, is critical for their antimicrobial function. A shared mechanism of bacterial escape from NET entrapment by means of extracellular DNAse production has now been described for GAS $(16,116)$, SPN (10), GBS (36), and $S$. aureus (13). For GAS, the acquisition of the potent bacteriophage-encoded DNAse Sda1 may have been a critical strep in the evolution of the hypervirulent M1T1 clone that has disseminated globally as a leading agent of severe invasive infections (124).

\section{ACCELERATED PHAGOCYTE DEATH BY CYTOLYTIC TOXINS}

A common feature of invasive gram-positive bacterial pathogens is the elaboration of potent membrane-damaging cytotoxins capable of targeting a variety of host cell membranes and important in the disruption and penetration of epithelial and endothelial barriers. Because phagocytic cell types such as neutrophils and macrophages are often vulnerable to these cytotoxic activities, another de facto mechanism for gram-positive innate immune evasion can involve triggering phagocytic cell death before bacterial killing can be fully accomplished.

S. aureus is notable for producing rapid necrosis of neutrophils following phagocytic uptake of the pathogen (69). S. aureus produces a family of two-subunit hetero-heptameric toxins that can oligomerize target leukocyte cell membranes to create pores and promote hypoosmotic cell lysis. These include $\gamma$-hemolysin, leukotoxin $\mathrm{ED}$, leukotoxin $\mathrm{GH}$, and the controversial bacteriophage-encoded Panton-Valentine leukocidin (PVL). Similarly the pore-forming GAS $\beta$-hemolysin streptolysin S (SLS) is cytolytic to human neutrophils and increases GAS resistance to phagocytic killing $(33,85)$.

Phenol-soluble modulins (PSMs) are a recently recognized group of small peptides produced by S. aureus with important roles in immune evasion and virulence (125). PSMs possess an amphipathic a-helical structure and membrane-destabilizing properties that can recruit, 
activate (71), and lyse neutrophils and induce a marked proinflammatory response while promoting bacterial survival. PSMs allow $S$. aureus to escape the phagolysosome and replicate intracellularly (43). PSMs can also act synergistically to exaggerate the cytolytic effect of PVL on human neutrophils (51).

Structurally distinct from SLS, the GAS cholesterol-binding cytolysin SLO is also toxic to human neutrophils and helps the pathogen avoid lysosomal localization (46) and is a key virulence factor in animal models of invasive GAS infection $(33,76)$. Upon phagocytosis, GAS mediates a program of accelerated neutrophil apoptosis relative to other common human pathogens (70). SLO was shown to represent the key GAS proapoptotic factor through mitochondrial membrane damage and activation of canonical caspase pathways (117). Similarly, the GBS $\beta$-hemolysin/cytolysin is a pore-forming toxin that induces cytolysis and apoptosis of macrophages, thereby promoting bacterial survival and virulence in animal models of pulmonary and systemic infection (79). Pneumolysin, the thiol-activated cytolysin of SPN, has a complex relationship with host defense, inducing the necrosis and apoptosis of human neutrophils (133) and macrophage cell lines (48) but also triggering IL-8 production (28) and stimulating neutrophil transendothelial migration (86).

Recent data reveal that the host innate immune system has developed the means to detect subcytolytic concentrations of pore-forming cytolysins, through a mechanism involving activation of the NLRP3 inflammasome and release of the proinflammatory cytokine IL-1 $\beta$ (31). Thus, pore-forming toxins can both stimulate or disable host defense depending on expression levels, site, and magnitude of infection.

\section{FUTURE OUTLOOK AND THERAPEUTIC OPPORTUNITIES}

The clinical specialty of infection disease medicine might be accurately defined as those medical conditions that arise when there has been a failure of innate immune defense. Our review has highlighted the diverse array of molecular mechanisms by which leading human gram-positive pathogens counteract or disable critical elements of host phagocyte-based innate immune defense to survive in the host and produce invasive infection. Whereas each pathogen deploys a different suite of virulence factors, encoded by unique sets of genes and possessing unique chemical structures, the cumulative effect of these features provides each pathogen significant resistance to phagocyte recruitment and activation, opsonophagocytosis, bacterial entrapment and uptake, and the microbicidal activities of key host defense factors such as AMPs and ROS.

In the present day, the cornerstone for treatment of invasive bacterial infection remains classical antibiotics, which function to kill or suppress the growth of a broad spectrum of bacteria, coupled with supportive care measures in the hospital or intensive care unit setting. However, this approach faces ever-increasing challenges owing to the continual evolution of antibiotic resistance (e.g., MRSA/vancomycin-intermediate $S$. aureus, penicillin-resistant SPN), epidemics of hypervirulent pathogen clones, and expanding vulnerable patient groups. Broad-spectrum antibiotic therapy also markedly perturbs the normal human microflora, which is increasingly recognized to play a critical role in maintaining healthy physiology and immune function. 
The explosion of new knowledge regarding the immune evasion mechanisms of invasive gram-positive pathogens highlighted herein raises an interesting possibility: Could therapy of these leading disease agents be contemplated in a fashion that is not focused exclusively on the bacterium but rather more holistically on the host-pathogen interaction? Essentially, if a molecular mechanism of immune resistance is identified, the virulence factor itself could be explored as a therapeutic target, with the goal of resensitizing the pathogen to that particular arm of host innate defense (Figure 4). Such antivirulence therapies $(22,39)$ have the advantage in greater specificity and should not perturb or select for antibiotic resistance among the normal microflora. Virulence factor inhibitor treatments could also be used handin-hand with classical antibiotics for management of severe infections, including those complicated by antibiotic resistance or compromised host immunity. We have highlighted numerous studies employing targeted gene inactivation in leading gram-positive pathogens to produce isogenic mutants with increased susceptibility to innate immune clearance and reduced virulence in animal infection models. It is these gene-encoded pathogenicity factors that become pharmacologic targets, and literature is emerging to provide solid proofs-ofprinciple of therapeutic utility.

Recent approaches to limit S. aureus pathogenicity highlight this therapeutic strategy. A virulence factor discovery was exploited to design an approach to increase $S$. aureus sensitivity to ROS (Figure 4). The golden pigment staphyloxanthin was found to promote $S$. aureus virulence by neutralizing ROS-based neutrophil killing without affecting bacterial viability (80). Similarities were then recognized between the enzyme dehydrosqualene synthase (CrtM) in the biosynthetic pathway for staphyloxanthin and squalene synthase, an enzyme involved in human cholesterol biosynthesis. A cholesterol-lowering drug candidate targeting squalene synthetase (BPH-652) was found to block staphyloxanthin production, rendering the organism sensitive to ROS and neutrophil killing; treatment of mice with BPH-652 provided protection against systemic $S$. aureus infection (78). Additionally, given that blockade of cholesterol biosynthesis fortifies host defense against $S$. aureus by increasing NET production (26), dual specificity agents targeting CrtM and squalene synthesis have the potential to simultaneously boost neutrophil activity while sensitizing the pathogen to neutrophil-derived ROS (Figure 4) (77).

Targeting a specific virulence factor has also proven to be useful in limiting pathogenicity. Monoclonal antibodies to $S$. aureus a-hemolysin were shown to protect mice in pneumonia models (100). The lethal effects of a-hemolysin can also be blocked by administration of a cyclodextrin derivative that inhibits the assembled heptameric a-hemolysin pore in target cell membranes (101), or by treatment with novel biomimetic nanosponges composed of red blood cell membranes that absorb pore-forming toxins (52). The cellular receptor for ahemolysin is A-disintegrin and metalloprotease 10 (ADAM10), which can be blocked with a small molecule inhibitor of ADAM10 metalloprotease activity (54). More recently, the related U.S. Food and Drug Administration-approved nonsteroidal anti-inflammatory drug diflunisol was identified as a candidate inhibitor of the AgrA response regulator, proving to block a-hemolysin production by the pathogen (66). Therapeutic targeting of the gene regulatory pathways that control the pathogen's expression of key virulence determinants has also been investigated. One such example is the RNAII-inhibiting peptide (RIP), which 
has been shown to block Agr-dependent quorum sensing in $S$. aureus and to provide therapeutic benefit in several animal models of staphylococcal infections $(9,27)$.

Finally, targeting of host cell pathways to enhance bacterial clearance has also been investigated as a therapeutic strategy (Figure 4). Recently, the human immunodeficiency virus (HIV) co-receptor CCR5 was identified as a cellular determinant required for cytotoxic targeting of leukocytes by S. aureus leukotoxin ED (4). CCR5 knockout mice are more resistance to $S$. aureus infection, and treatment of normal mice with the HIV drug Maraviroc, a CCR5 inhibitor, conferred protection (4). Fascinatingly, in addition to increasing the capacity of neutrophils to produce NETs (26), statin treatment and lowering cholesterol levels in cell membranes reduced host cell lysis by the cholesterol-dependent SPN cytotoxin pneumolysin, helping protect against fulminant pneumococcal infection in an experimental mouse model of sickle cell anemia (105a).

In summary, a continued focus on deciphering the specific determinants responsible for innate immune evasion by invasive gram-positive pathogens so as to design specific virulence factor inhibitors can add to the future arsenal of therapeutic options available to physicians. Additionally, recent data suggest that even certain classical antibiotics may exert immune-sensitizing activities at subtherapeutic concentrations or against strains deemed resistant by classical minimum inhibitory concentration (MIC)/minimum bactericidal concentration (MBC) testing $(6,107)$. Furthermore, the development of drugs that enhance the ability of host cells to eliminate bacterial pathogens limits the development of drugresistant bacteria and tips the balance of the host-microbe interaction in favor of the host (Figure 4). In the current era of increasing antibiotic resistance and complex hospitalized patient populations, it is hard to envision winning the battle against the leading invasive gram-positive pathogens without harnessing the power of our innate immune system.

\section{Acknowledgments}

\section{DISCLOSURE STATEMENT}

V.N. is co-inventor on patents (PCT/US2006/014486, PCT/US2007/011466) regarding pharmacological inhibition of $S$. aureus staphyloxanthin licensed by Wildcat Ventures, Houston, TX. The authors are not aware of any other affiliations, memberships, funding, or financial holdings that might be perceived as affecting the objectivity of this review.

\section{TERMS AND DEFINITIONS}
AMPs
antimicrobial peptides, sequences of 12-50 amino acids that have direct antimicrobial activity and are generated from a precursor protein
C4BP
fMLP
GAS
GBS
C4b-binding protein complement: a system of 30 proteins that aid in opsonization, chemoattraction, and direct antimicrobial activity formyl-methionyl-leucyl-phenylalanine peptide group A Streptococcus group B Streptococcus 
NETs

opsonophagocytosis

PRR

PSM

ROS

SPN

TLR neutrophil extracellular traps, an antimicrobial decondensed chromatin structure released from neutrophils containing histones, AMPs, and granule proteases

phagocytosis initiated by recognition of an opsonin by a host cell receptor

pattern-recognition receptor

phenol-soluble modulin

reactive oxygen species; highly antimicrobial reactive oxygencontaining chemical species and radicals

Streptococcus pneumonia

Toll-like receptor

\section{LITERATURE CITED}

1. Agarwal V, Ahl J, Riesbeck K, Blom AM. An alternative role of C1q in bacterial infections: facilitating Streptococcus pneumoniae adherence and invasion of host cells. J. Immunol. 2013; 191:4235-4245. [PubMed: 24038089]

2. Agarwal V, Hammerschmidt S, Malm S, Bergmann S, Riesbeck K, Blom AM. Enolase of Streptococcus pneumoniae binds human complement inhibitor C4b-binding protein and contributes to complement evasion. J. Immunol. 2012; 189:3575-3584. [PubMed: 22925928]

3. Agarwal V, Kuchipudi A, Fulde M, Riesbeck K, Bergmann S, Blom AM. Streptococcus pneumoniae endopeptidase $\mathrm{O}(\mathrm{PepO})$ is a multifunctional plasminogen- and fibronectin-binding protein, facilitating evasion of innate immunity and invasion of host cells. J. Biol. Chem. 2013; 288:6849-6863. [PubMed: 23341464]

4. Alonzo F 3rd, Kozhaya L, Rawlings SA, Reyes-Robles T, DuMont AL, et al. CCR5 is a receptor for Staphylococcus aureus leukotoxin ED. Nature. 2013; 493:51, 55. [PubMed: 23235831] Discovery of CCR5 as the receptor for a staphylococcal pore-forming toxin.

5. Amulic B, Cazalet C, Hayes GL, Metzler KD, Zychlinsky A. Neutrophil function: from mechanisms to disease. Annu. Rev. Immunol. 2012; 30:459-489. [PubMed: 22224774]

6. Anderson R, Steel HC, Cockeran R, Smith AM, von Gottberg A, et al. Clarithromycin alone and in combination with ceftriaxone inhibits the production of pneumolysin by both macrolide-susceptible and macrolide-resistant strains of Streptococcus pneumoniae. J. Antimicrob. Chemother. 2007; 59:224-229. [PubMed: 17218449]

7. Askariana F, van Sorge NM, Sangvika M, Beasley FC, Henriksend JR, et al. A Staphylococcus aureus TIR-domain protein virulence factor blocks TLR2-mediated NF- $\kappa \mathrm{B}$ signaling. J. Innate Immun. 2014 In press.

8. Atilano ML, Yates J, Glittenberg M, Filipe SR, Ligoxygakis P. Wall teichoic acids of Staphylococcus aureus limit recognition by the Drosophila peptidoglycan recognition protein-SA to promote pathogenicity. PLoS Pathog. 2011; 7:e1002421. [PubMed: 22144903]

9. Balaban N, Cirioni O, Giacometti A, Ghiselli R, Braunstein JB, et al. Treatment of Staphylococcus aureus biofilm infection by the quorum-sensing inhibitor RIP. Antimicrob. Agents Chemother. 2007; 51:2226-2229. [PubMed: 17371825]

10. Beiter K, Wartha F, Albiger B, Normark S, Zychlinsky A, Henriques-Normark B. An endonuclease allows Streptococcus pneumoniae to escape from neutrophil extracellular traps. Curr. Biol. 2006; 16:401-407. [PubMed: 16488875]

11. Bera A, Biswas R, Herbert S, Kulauzovic E, Weidenmaier C, et al. Influence of wall teichoic acid on lysozyme resistance in Staphylococcus aureus. J. Bacteriol. 2006; 189:280-283. [PubMed: 17085565] 
12. Berends ETM, Dekkers JF, Nijland R, Kuipers A, Soppe JA, et al. Distinct localization of the complement C5b-9 complex on gram-positive bacteria. Cell Microbiol. 2013; 5:1955-1968. [PubMed: 23869880]

13. Berends ETM, Horswill AR, Haste NM, Monestier M, Nizet V, von Köckritz-Blickwede M. Nuclease expression by Staphylococcus aureus facilitates escape from neutrophil extracellular traps. J. Innate Immun. 2010; 2:576-586. [PubMed: 20829609]

14. Brown S, Santa Maria J, John P, Walker S. Wall teichoic acids of gram-positive bacteria. Annu. Rev. Microbiol. 2013; 67:313-336. [PubMed: 24024634]

15. Bryan JD, Shelver DW. Streptococcus agalactiae CspA is a serine protease that inactivates chemokines. J. Bacteriol. 2009; 191:1847-1854. [PubMed: 19114481]

16. Buchanan JT, Simpson AJ, Aziz RK, Liu GY, Kristian SA, et al. DNase expression allows the pathogen group A Streptococcus to escape killing in neutrophil extracellular traps. Curr. Biol. 2006; 16:396-400. [PubMed: 16488874]

17. Carapetis JR, Steer AC, Mulholland EK, Weber M. The global burden of group A streptococcal diseases. Lancet Infect. Dis. 2005; 5:685-694. [PubMed: 16253886]

18. Carlin AF, Chang Y-C, Areschoug T, Lindahl G, Hurtado-Ziola N, et al. Group B Streptococcus suppression of phagocyte functions by protein-mediated engagement of human Siglec-5. J. Exp. Med. 2009; 206:1691-1699. [PubMed: 19596804]

19. Carlin AF, Lewis AL, Varki A, Nizet V. Group B streptococcal capsular sialic acids interact with siglecs (immunoglobulin-like lectins) on human leukocytes. J. Bacteriol. 2007; 189:1231-1237. [PubMed: 16997964]

20. Carlin AF, Uchiyama S, Chang Y-C, Lewis AL, Nizet V, Varki A. Molecular mimicry of host sialylated glycans allows a bacterial pathogen to engage neutrophil Siglec-9 and dampen the innate immune response. Blood. 2009; 113:3333-3336. [PubMed: 19196661]

21. Carlsson F, Sandin C, Lindahl G. Human fibrinogen bound to Streptococcus pyogenes M protein inhibits complement deposition via the classical pathway. Mol. Microbiol. 2005; 56:28-39. [PubMed: 15773976]

22. Cegelski L, Marshall GR, Eldridge GR, Hultgren SJ. The biology and future prospects of antivirulence therapies. Nat. Rev. Microbiol. 2008; 6:17-27. [PubMed: 18079741]

23. Chang YC, Olson J, Beasley FC, Tung C, Zhang J, et al. Group B Streptococcus engages an inhibitory Siglec through sialic acid mimicry to blunt innate immune and inflammatory responses in vivo. PLoS Pathog. 2014; 10:e1003846. [PubMed: 24391502]

24. Charrel-Dennis M, Latz E, Halmen KA, Trieu-Cuot P, Fitzgerald KA, et al. TLR-independent type I interferon induction in response to an extracellular bacterial pathogen via intracellular recognition of its DNA. Cell Host Microbe. 2008; 4:543-554. [PubMed: 19064255]

25. Cho JH. Human peptidoglycan recognition protein $\mathrm{S}$ is an effector of neutrophil-mediated innate immunity. Blood. 2005; 106:2551-2558. [PubMed: 15956276]

26. Chow OA, von Kockritz-Blickwede M, Bright AT, Hensler ME, Zinkernagel AS, et al. Statins enhance formation of phagocyte extracellular traps. Cell Host Microbe. 2010; 8:445-454. [PubMed: 21075355]

27. Cirioni O, Giacometti A, Ghiselli R, Dell'Acqua G, Orlando F, et al. RNAIII-inhibiting peptide significantly reduces bacterial load and enhances the effect of antibiotics in the treatment of central venous catheter--associated Staphylococcus aureus infections. J. Infect. Dis. 2006; 193:180-186. [PubMed: 16362881]

28. Cockeran R, Durandt C, Feldman C, Mitchell TJ, Anderson R. Pneumolysin activates the synthesis and release of interleukin- 8 by human neutrophils in vitro. J. Infect. Dis. 2002; 186:562-565. [PubMed: 12195386]

29. Cole JN, Pence MA, von Kockritz-Blickwede M, Hollands A, Gallo RL, et al. M protein and hyaluronic acid capsule are essential for in vivo selection of $\operatorname{cov} R S$ mutations characteristic of invasive serotype M1T1 group A Streptococcus. Mbio. 2010; 1:e00191-e00110. [PubMed: 20827373]

30. Collin M, Svensson MD, Sjoholm AG, Jensenius JC, Sjobring U, Olsen A. EndoS and SpeB from Streptococcus pyogenes inhibit immunoglobulin-mediated opsonophagocytosis. Infect. Immun. 2002; 70:6646-6651. [PubMed: 12438337] 
31. Costa A, Gupta R, Signorino G, Malara A, Cardile F, et al. Activation of the NLRP3 inflammasome by Group B streptococci. J. Immunol. 2012; 188:1953-1960. [PubMed: 22250086]

32. Crisostomo MI, Vollmer W, Kharat AS, Inhulsen S, Gehre F, et al. Attenuation of penicillin resistance in a peptidoglycan $O$-acetyl transferase mutant of Streptococcus pneumoniae. Mol. Microbiol. 2006; 61:1497-1509. [PubMed: 16968223]

33. Datta V, Myskowski SM, Kwinn LA, Chiem DN, Varki N, et al. Mutational analysis of the group A streptococcal operon encoding streptolysin $\mathrm{S}$ and its virulence role in invasive infection. Mol. Microbiol. 2005; 56:681-695. [PubMed: 15819624]

34. Dave S, Brooks-Walter A, Pangburn MK, McDaniel LS. PspC, a pneumococcal surface protein, binds human factor H. Infect. Immun. 2001; 69:3435-3437. [PubMed: 11292770]

35. Davis KM, Nakamura S, Weiser JN. Nod2 sensing of lysozyme-digested peptidoglycan promotes macrophage recruitment and clearance of $S$. pneumoniae colonization in mice. J. Clin. Invest. 2011; 121:3666-3676. [PubMed: 21841315] S. pneumoniae prevents lysozyme recognition, evading intracellular PRR detection and activation of the inflammatory response.

36. Derré-Bobillot A, Cortes-Perez NG, Yamamoto Y, Kharrat P, Couvé E, et al. Nuclease A (Gbs0661), an extracellular nuclease of Streptococcus agalactiae, attacks the neutrophil extracellular traps and is needed for full virulence. Mol. Microbiol. 2013; 89:518-531. [PubMed: 23772975]

37. DuMont AL, Yoong P, Surewaard BGJ, Benson MA, Nijland R, et al. Staphylococcus aureus elaborates leukocidin AB to mediate escape from within human neutrophils. Infect. Immun. 2013; 81:1830-1841. [PubMed: 23509138]

38. Ermert D, Weckel A, Agarwal V, Frick IM, Björck L, Blom AM. Binding of complement inhibitor C4b-binding protein to a highly virulent Streptococcus pyogenes M1 strain is mediated by protein $\mathrm{H}$ and enhances adhesion to and invasion of endothelial cells. J. Biol. Chem. 2013; 288:3217232183. [PubMed: 24064215]

39. Escaich S. Antivirulence as a new antibacterial approach for chemotherapy. Curr. Opin. Chem. Biol. 2008; 12:400-408. [PubMed: 18639647]

40. Farshchi Andisi V, Hinojosa CA, de Jong A, Kuipers OP, Orihuela CJ, Bijlsma JJE. Pneumococcal gene complex involved in resistance to extracellular oxidative stress. Infect. Immun. 2012; 80:1037-1049. [PubMed: 22215735]

41. Gallis HA, Miller SE, Wheat RW. Degradation of 14C-labeled streptococcal cell walls by egg white lysozyme and lysosomal enzymes. Infect. Immun. 1976; 13:1459-1466. [PubMed: 773836]

42. Gratz N, Siller M, Schaljo B, Pirzada ZA, Gattermeier I, et al. Group A Streptococcus activates type I interferon production and MyD88-dependent signaling without involvement of TLR2, TLR4, and TLR9. J. Biol. Chem. 2008; 283:19879-19887. [PubMed: 18480050]

43. Grosz M, Kolter J, Paprotka K, Winkler A-C, Schäfer D, et al. Cytoplasmic replication of Staphylococcus aureus upon phagosomal escape triggered by phenol-soluble modulin a. Cell Microbiol. 2014 In press.

44. Gusarov I, Shatalin K, Starodubtseva M, Nudler E. Endogenous nitric oxide protects bacteria against a wide spectrum of antibiotics. Science. 2009; 325:1380-1384. [PubMed: 19745150] Discovery of unexpected contribution of $S$. aureus bNOS production to oxidant defense.

45. Hair PS, Echague CG, Sholl AM, Watkins JA, Geoghegan JA, et al. Clumping factor A interaction with complement factor I increases C3b cleavage on the bacterial surface of Staphylococcus aureus and decreases complement-mediated phagocytosis. Infect. Immun. 2010; 78:1717-1727. [PubMed: 20100856]

46. Hakansson A, Bentley CC, Shakhnovic EA, Wessels MR. Cytolysin-dependent evasion of lysosomal killing. Proc. Natl. Acad. Sci. USA. 2005; 102:5192-5197. [PubMed: 15795386]

47. Henneke P, Takeuchi O, Malley R, Lien E, Ingalls RR, et al. Cellular activation, phagocytosis, and bactericidal activity against group B streptococcus involve parallel myeloid differentiation factor 88-dependent and independent signaling pathways. J. Immunol. 2002; 169:3970-3977. [PubMed: 12244198]

48. Hirst RA, Yesilkaya H, Clitheroe E, Rutman A, Dufty N, et al. Sensitivities of human monocytes and epithelial cells to pneumolysin are different. Infect. Immun. 2002; 70:1017-1022. [PubMed: 11796644] 
48a. Holden JK, Li H, Jing Q, Kang S, Richo J, et al. Structural and biological studies on bacterial nitric oxide synthase inhibitors. Proc. Natl. Acad. Sci. USA. 2013; 110:18127-18131. [PubMed: 24145412]

49. Hollands A, Gonzalez D, Leire E, Donald C, Gallo RL, et al. A bacterial pathogen co-opts host plasmin to resist killing by cathelicidin antimicrobial peptides. J. Biol. Chem. 2012; 287:4089140897. [PubMed: 23038245]

50. Honda-Ogawa M, Ogawa T, Terao Y, Sumitomo T, Nakata M, et al. Cysteine proteinase from Streptococcus pyogenes enables evasion of innate immunity via degradation of complement factors. J. Biol. Chem. 2013; 288:15854-15864. [PubMed: 23589297]

51. Hongo I, Baba T, Oishi K, Morimoto Y, Ito T, Hiramatsu K. Phenol-soluble modulin a 3 enhances the human neutrophil lysis mediated by Panton-Valentine leukocidin. J. Infect. Dis. 2009; 200:715-723. [PubMed: 19653829]

52. Hu CM, Fang RH, Copp J, Luk BT, Zhang L. A biomimetic nanosponge that absorbs pore-forming toxins. Nat. Nanotech. 2013; 8:336-340.

53. Hyams C, Camberlein E, Cohen JM, Bax K, Brown JS. The Streptococcus pneumoniae capsule inhibits complement activity and neutrophil phagocytosis by multiple mechanisms. Infect. Immun. 2010; 78:704-715. [PubMed: 19948837]

54. Inoshima I, Inoshima N, Wilke GA, Powers ME, Frank KM, et al. A Staphylococcus aureus poreforming toxin subverts the activity of ADAM10 to cause lethal infection in mice. Nat. Med. 2011; 17:1310-1314. [PubMed: 21926978]

55. Janowiak BE. Glutathione synthesis in Streptococcus agalactiae: One protein accounts for $\gamma$ glutamylcysteine synthetase and glutathione synthetase activities. J. Biol. Chem. 2005; 280:11829-11839. [PubMed: 15642737]

56. Jarva H, Hellwage J, Jokiranta TS, Lehtinen MJ, Zipfel PF, Meri S. The group B streptococcal $\beta$ and pneumococcal Hic proteins are structurally related immune evasion molecules that bind the complement inhibitor factor $\mathrm{H}$ in an analogous fashion. J. Immunol. 2004; 172:3111-3118. [PubMed: 14978117]

57. Jin T, Bokarewa M, Foster T, Mitchell J, Higgins J, Tarkowski A. Staphylococcus aureus resists human defensins by production of staphylokinase, a novel bacterial evasion mechanism. J. Immunol. 2004; 172:1169-1176. [PubMed: 14707093]

58. Johansson L, Thulin P, Sendi P, Hertzén E, Linder A, et al. Cathelicidin LL-37 in severe Streptococcus pyogenes soft tissue infections in humans. Infect. Immun. 2008; 76:3399-3404. [PubMed: 18490458]

59. Jones AL, Mertz RH, Carl DJ, Rubens CE. A streptococcal penicillin-binding protein is critical for resisting innate airway defenses in the neonatal lung. J. Immunol. 2007; 179:3196-3202. [PubMed: 17709535]

60. Jongerius I, Kohl J, Pandey MK, Ruyken M, van Kessel KPM, et al. Staphylococcal complement evasion by various convertase-blocking molecules. J. Exp. Med. 2007; 204:2461-2471. [PubMed: 17893203]

61. Jusko M, Potempa J, Kantyka T, Bielecka E, Miller HK, et al. Staphylococcal proteases aid in evasion of the human complement system. J. Innate Immun. 2014; 6:31-46. [PubMed: 23838186]

62. Kagawa TF, O’Connell MR, Mouat P, Paoli M, O’Toole PW, Cooney JC. Model for substrate interactions in C5a peptidase from Streptococcus pyogenes: A $1.9 \AA$ crystal structure of the active form of ScpA. J. Mol. Biol. 2009; 386:754-772. [PubMed: 19152799]

63. Kang M, Ko YP, Liang X, Ross CL, Liu Q, et al. Collagen-binding microbial surface components recognizing adhesive matrix molecule (MSCRAMM) of gram-positive bacteria inhibit complement activation via the classical pathway. J. Biol. Chem. 2013; 288:20520-20531. [PubMed: 23720782]

64. Kaplan A, Ma J, Kyme P, Wolf AJ, Becker CA, et al. Failure to induce IFN- $\beta$ production during Staphylococcus aureus infection contributes to pathogenicity. J. Immunol. 2012; 189:4537-4545. [PubMed: 23008447]

65. Karavolos MH. Role and regulation of the superoxide dismutases of Staphylococcus aureus. Microbiology. 2003; 149:2749-2758. [PubMed: 14523108] 
66. Khodaverdian V, Pesho M, Truitt B, Bollinger L, Patel P, et al. Discovery of antivirulence agents against methicillin-resistant Staphylococcus aureus. Antimicrob. Agents Chemother. 2013; 57:3645-3652. [PubMed: 23689713]

67. Kim HK, Thammavongsa V, Schneewind O, Missiakas D. Recurrent infections and immune evasion strategies of Staphylococcus aureus. Curr. Opin. Microbiol. 2012; 15:92-99. [PubMed: 22088393]

68. Knapp S, Wieland CW, van 't Veer C, Takeuchi O, Akira S, et al. Toll-like receptor 2 plays a role in the early inflammatory response to murine pneumococcal pneumonia but does not contribute to antibacterial defense. J. Immunol. 2004; 172:3132-3138. [PubMed: 14978119]

69. Kobayashi SD, Braughton KR, Palazzolo-Ballance AM, Kennedy AD, Sampaio E, et al. Rapid neutrophil destruction following phagocytosis of Staphylococcus aureus. J. Innate Immun. 2010; 2:560-575. [PubMed: 20587998]

70. Kobayashi SD, Braughton KR, Whitney AR, Voyich JM, Schwan TG, et al. Bacterial pathogens modulate an apoptosis differentiation program in human neutrophils. Proc. Natl. Acad. Sci. USA. 2003; 100:10948-10953. [PubMed: 12960399]

71. Kretschmer D, Gleske AK, Rautenberg M, Wang R, Koberle M, et al. Human formyl peptide receptor 2 senses highly pathogenic Staphylococcus aureus. Cell Host Microbe. 2010; 7:463-473. [PubMed: 20542250]

72. Kristian SA, Datta V, Weidenmaier C, Kansal R, Fedtke I, et al. d-alanylation of teichoic acids promotes group A streptococcus antimicrobial peptide resistance, neutrophil survival, and epithelial cell invasion. J. Bacteriol. 2005; 187:6719-6725. [PubMed: 16166534]

73. Laarman AJ, Ruyken M, Malone CL, van Strijp JAG, Horswill AR, Rooijakkers SHM. Staphylococcus aureus metalloprotease aureolysin cleaves complement C3 to mediate immune evasion. J. Immunol. 2011; 186:6445-6453. [PubMed: 21502375]

74. Lauth X, von Köckritz-Blickwede M, McNamara CW, Myskowski S, Zinkernagel AS, et al. M1 Protein allows group A streptococcal survival in phagocyte extracellular traps through cathelicidin inhibition. J. Innate Immun. 2009; 1:202-214. [PubMed: 20375578]

74a. Lee J-H, Cho HS, Kim Y, Kim J-A, Banskota S, et al. Indole and 7-benzyloxyindole attenuate the virulence of Staphylococcus aureus. Appl. Microbiol. Biotechnol. 2013; 97:4543-4552. [PubMed: 23318836]

75. Lei B, DeLeo FR, Hoe NP, Graham MR, Mackie SM, et al. Evasion of human innate and acquired immunity by a bacterial homolog of CD11b that inhibits opsonophagocytosis. Nat. Med. 2001; 7:1298-1305. [PubMed: 11726969]

76. Limbago B, Penumalli V, Weinrick B, Scott JR. Role of streptolysin O in a mouse model of invasive group A streptococcal disease. Infect. Immun. 2000; 68:6384-6390. [PubMed: 11035749]

77. Lin FY, Zhang Y, Hensler M, Liu YL, Chow OA, et al. Dual dehydrosqualenesqualene synthase inhibitors: leads for innate immune system-based therapeutics. ChemMedChem. 2012; 7:561-564. [PubMed: 22290830]

78. Liu CI, Liu GY, Song Y, Yin F, Hensler ME, et al. A cholesterol biosynthesis inhibitor blocks Staphylococcus aureus virulence. Science. 2008; 319:1391-1394. [PubMed: 18276850] Provides approach to repositioning a human cholesterol drug lead to block pigment production and virulence

79. Liu GY, Doran KS, Lawrence T, Turkson N, Puliti M, et al. Sword and shield: linked group B streptococcal $\beta$-hemolysincytolysin and carotenoid pigment function to subvert host phagocyte defense. Proc. Natl. Acad. Sci. USA. 2004; 101:14491-14496. [PubMed: 15381763]

80. Liu GY, Essex A, Buchanan JT, Datta V, Hoffman HM, et al. Staphylococcus aureus golden pigment impairs neutrophil killing and promotes virulence through its antioxidant activity. J. Exp. Med. 2005; 202:209-215. [PubMed: 16009720]

81. Ly D, Taylor JM, Tsatsaronis JA, Monteleone MM, Skora AS, et al. Plasmin(ogen) acquisition by group A Streptococcus protects against C3b-mediated neutrophil killing. J. Innate Immun. 2014; 6:340-350.

82. Maisey HC, Quach D, Hensler ME, Liu GY, Gallo RL, et al. A group B streptococcal pilus protein promotes phagocyte resistance and systemic virulence. FASEB J. 2008; 22:1715-1724. [PubMed: 18198218] 
83. Marques MB, Kasper DL, Pangburn MK, Wessels MR. Prevention of C3 deposition by capsular polysaccharide is a virulence mechanism of type III group B streptococci. Infect. Immun. 1992; 60:3986-3993. [PubMed: 1398910]

84. McNeela EA, Burke Á, Neill DR, Baxter C, Fernandes VE, et al. Pneumolysin activates the NLRP3 inflammasome and promotes proinflammatory cytokines independently of TLR4. PLoS Pathog. 2010; 6:e1001191. [PubMed: 21085613]

85. Miyoshi-Akiyama T, Takamatsu D, Koyanagi M, Zhao J, Imanishi K, Uchiyama T. Cytocidal effect of Streptococcus pyogenes on mouse neutrophils in vivo and the critical role of streptolysin S. J. Infect. Dis. 2005; 192:107-116. [PubMed: 15942900]

86. Moreland JG, Bailey G. Neutrophil transendothelial migration in vitro to Streptococcus pneumoniae is pneumolysin dependent. Am. J. Physiol. Lung. Cell Mol. Physiol. 2006; 290:L833L840. [PubMed: 16339781]

86a. Niemann S, Kehrel BE, Heilmann C, Rennemeier C, Peters G, Hammerschmidt S. Pneumococcal association to platelets is mediated by soluble fibrin and supported by thrombospondin-1.

Thromb. Haemost. 2009; 102:735-742. [PubMed: 19806260]

87. Nishi H, Komatsuzawa H, Fujiwara T, McCallum N, Sugai M. Reduced content of lysylphosphatidylglycerol in the cytoplasmic membrane affects susceptibility to moenomycin, as well as vancomycin, gentamicin, and antimicrobial peptides, in Staphylococcus aureus. Antimicrob. Agents Chemother. 2004; 48:4800-4807. [PubMed: 15561859]

88. Nordenfelt P, Grinstein S, Björck L, Tapper H. V-ATPase-mediated phagosomal acidification is impaired by Streptococcus pyogenes through Mga-regulated surface proteins. Microb. Infect. 2012; 14:1319-1329.

89. Nordenfelt P, Waldemarson S, Linder A, Morgelin M, Karlsson C, et al. Antibody orientation at bacterial surfaces is related to invasive infection. J. Exp. Med. 2012; 209:2367-2381. [PubMed: 23230002]

90. O’Brien KL, Wolfson LJ, Watt JP, Henkle E, Deloria-Knoll M, et al. Burden of disease caused by Streptococcus pneumoniae in children younger than 5 years: global estimates. Lancet. 2009; 374:893-902. [PubMed: 19748398]

91. Okumura CYM, Anderson EL, Dohrmann S, Tran DN, Olson J, et al. IgG protease MacIdeS is not essential for phagocyte resistance or mouse virulence of M1T1 group A Streptococcus. Mbio. 2013; 4:e00499-13-e99. [PubMed: 23900173]

92. O'Seaghdha M, Wessels MR. Streptolysin O and its co-toxin NAD-glycohydrolase protect group A Streptococcus from xenophagic killing. PLoS Pathog. 2013; 9:e1003394. [PubMed: 23762025]

93. Pandiripally V, Gregory E, Cue D. Acquisition of regulators of complement activation by Streptococcus pyogenes serotype M1. Infect. Immun. 2002; 70:6206-6214. [PubMed: 12379699]

94. Pence MA, Rooijakkers SHM, Cogen AL, Cole JN, Hollands A, et al. Streptococcal inhibitor of complement promotes innate immune resistance phenotypes of invasive M1T1 group A Streptococcus. J. Innate Immun. 2010; 2:587-595. [PubMed: 20814187]

95. Persson H, Vindebro R, von Pawel-Rammingen U. The streptococcal cysteine protease SpeB is not a natural immunoglobulin-cleaving enzyme. Infect. Immun. 2013; 81:2236-2241. [PubMed: 23569114]

96. Peschel A. Inactivation of the dlt operon in Staphylococcus aureus confers sensitivity to defensins, protegrins, and other antimicrobial peptides. J. Biol. Chem. 1999; 274:8405-8410. [PubMed: 10085071]

97. Poyart C, Pellegrini E, Marceau M, Baptista M, Jaubert F, et al. Attenuated virulence of Streptococcus agalactiae deficient in d-alanyl-lipoteichoic acid is due to an increased susceptibility to defensins and phagocytic cells. Mol. Microbiol. 2003; 49:1615-1625. [PubMed: 12950925]

98. Prat C, Bestebroer J, de Haas CJ, van Strijp JA, van Kessel KP. A new staphylococcal antiinflammatory protein that antagonizes the formyl peptide receptor-like 1. J. Immunol. 2006; 177:8017-8026. [PubMed: 17114475]

99. Prokesova L, Potuznikova B, Potempa J, Zikan J, Radl J, et al. Cleavage of human immunoglobulins by serine proteinase from Staphylococcus aureus. Immunol. Lett. 1992; 31:259265. [PubMed: 1372285] 
100. Ragle BE, Bubeck Wardenburg J. Anti-alpha-hemolysin monoclonal antibodies mediate protection against Staphylococcus aureus pneumonia. Infect. Immun. 2009; 77:2712-2718. [PubMed: 19380475]

101. Ragle BE, Karginov VA, Bubeck Wardenburg J. Prevention and treatment of Staphylococcus aureus pneumonia with a $\beta$-cyclodextrin derivative. Antimicrob. Agents Chemother. 2010; 54:298-304. [PubMed: 19805564]

102. Ray A, Cot M, Puzo G, Gilleron M, Nigou J. Bacterial cell wall macroamphiphiles: pathogenmicrobe-associated molecular patterns detected by mammalian innate immune system. Biochimie. 2013; 95:33-42. [PubMed: 22706280]

103. Rooijakkers SH, Ruyken M, Roos A, Daha MR, Presanis JS, et al. Immune evasion by a staphylococcal complement inhibitor that acts on C3 convertases. Nat. Immunol. 2005; 6:920 927. [PubMed: 16086019] Staphylococcal virulence factor cripples a key step in complement activation.

104. Rooijakkers SHM, van Strijp JAG. Bacterial complement evasion. Mol. Immunol. 2007; 44:2332. [PubMed: 16875737]

105. Rooijakkers SHM, van Wamel WJB, Ruyken M, van Kessel KPM, van Strijp JAG. Anti-opsonic properties of staphylokinase. Microb. Infect. 2005; 7:476-484.

105a. Rosch JW, Boyd AR, Hinojosa E, Pestina T, Hu Y, et al. Statins protect against fulminant pneumococcal infection and cytolysin toxicity in a mouse model of sickle cell disease. J. Clin. Invest. 2010; 120:627-635. [PubMed: 20093777]

106. Saar-Dover R, Bitler A, Nezer R, Shmuel-Galia L, Firon A, et al. d-Alanylation of lipoteichoic acids confers resistance to cationic peptides in group B Streptococcus by increasing the cell wall density. PLoS Pathog. 2012; 8:e1002891. [PubMed: 22969424]

107. Sakoulas G, Okumura CY, Thienphrapa W, Olson J, Nonejuie P, et al. Nafcillin enhances innate immune-mediated killing of methicillin-resistant Staphylococcus aureus. J. Mol. Med. 2014; 92:139-149. [PubMed: 24297496]

108. Saleh M, Bartual SG, Abdullah MR. Molecular architecture of Streptococcus pneumoniae surface thioredoxin-fold lipoproteins crucial for extracellular oxidative stress resistance and maintenance of virulence. EMBO Mol. Med. 2013; 12:1852-1870. [PubMed: 24136784]

109. Shimada T, Park BG, Wolf AJ, Brikos C, Goodridge HS, et al. Staphylococcus aureus evades lysozyme-based peptidoglycan digestion that links phagocytosis, inflammasome activation, and IL-1 $\beta$ secretion. Cell Host Microbe. 2010; 7:38-49. [PubMed: 20114027] Staphylococcal virulence factor cripples a key step in complement activation.

110. Sieprawska-Lupa M, Mydel P, Krawczyk K, Wojcik K, Puklo M, et al. Degradation of human antimicrobial peptide LL-37 by Staphylococcus aureus-derived proteinases. Antimicrob. Agents Chemother. 2004; 48:4673-4679. [PubMed: 15561843]

111. Sjögren J, Okumura CYM, Collin M, Nizet V, Hollands A. Study of the IgG endoglycosidase EndoS in group A streptococcal phagocyte resistance and virulence. BMC Microbiol. 2011; 11:120. [PubMed: 21619648]

112. Staali L, Bauer S, Mörgelin M, Björck L, Tapper H. Streptococcus pyogenes bacteria modulate membrane traffic in human neutrophils and selectively inhibit azurophilic granule fusion with phagosomes. Cell Microbiol. 2006; 8:690-703. [PubMed: 16548894]

113. Stafslien DK, Cleary PP. Characterization of the streptococcal C5a peptidase using a C5a-green fluorescent protein fusion protein substrate. J. Bacteriol. 2000; 182:3254-3258. [PubMed: 10809707]

114. Standish AJ, Weiser JN. Human neutrophils kill Streptococcus pneumoniae via serine proteases. J. Immunol. 2009; 183:2602-2609. [PubMed: 19620298]

115. Stemerding AM, Kohl J, Pandey MK, Kuipers A, Leusen JH, et al. Staphylococcus aureus formyl peptide receptor-like 1 inhibitor (FLIPr) and its homologue FLIPr-like are potent FcR antagonists that inhibit IgG-mediated effector functions. J. Immunol. 2013; 191:353-362. [PubMed: 23740955]

116. Sumby P, Barbian KD, Gardner DJ, Whitney AR, Welty DM, et al. Extracellular deoxyribonuclease made by group A Streptococcus assists pathogenesis by enhancing evasion of 
the innate immune response. Proc. Natl. Acad. Sci. USA. 2005; 102:1679-1684. [PubMed: 15668390]

117. Timmer AM, Timmer JC, Pence MA, Hsu LC, Ghochani M, et al. Streptolysin O promotes group A Streptococcus immune evasion by accelerated macrophage apoptosis. J. Biol. Chem. 2009; 284:862-871. [PubMed: 19001420]

118. Tsou CC, Chiang-Ni C, Lin YS, Chuang WJ, Lin MT, et al. An iron-binding protein, Dpr, decreases hydrogen peroxide stress and protects Streptococcus pyogenes against multiple stresses. Infect. Immun. 2008; 76:4038-4045. [PubMed: 18541662]

119. Uchiyama S, Andreoni F, Schuepbach RA, Nizet V, Zinkernagel AS. DNase Sda1 allows invasive M1T1 group A Streptococcus to prevent TLR9-dependent recognition. PLoS Pathog. 2012; 8:e1002736. [PubMed: 22719247]

120. Uhlemann AC, Otto M, Lowy FD, DeLeo FR. Evolution of community- and healthcareassociated methicillin-resistant Staphylococcus aureus. Infect. Genet. Evol. 2013; 21:563-574. [PubMed: 23648426]

120a. van Sorge NM, Beasley FC, Gusarov I, Gonzalez DJ, von Köckritz-Blickwede M, et al. Methicillin-resistant Staphylococcus aureus Bacterial Nitric-oxide Synthase Affects Antibiotic Sensitivity and Skin Abscess Development. J. Biol. Chem. 2013; 288:6417-6426. [PubMed: 23322784]

121. Verani JR, Schrag SJ. Group B streptococcal disease in infants: progress in prevention and continued challenges. Clin. Perinatol. 2010; 37:375-392. [PubMed: 20569813]

122. Vollmer W. The $p g d A$ gene encodes for a peptidoglycan $N$-acetylglucosamine deacetylase in Streptococcus pneumoniae. J. Biol. Chem. 2000; 275:20496-20501. [PubMed: 10781617]

123. von Köckritz-Blickwede M, Nizet V. Innate immunity turned inside-out: antimicrobial defense by phagocyte extracellular traps. J. Mol. Med. 2009; 87:775-783. [PubMed: 19444424]

124. Walker MJ, Hollands A, Sanderson-Smith ML, Cole JN, Kirk JK, et al. DNase Sda1 provides selection pressure for a switch to invasive group A streptococcal infection. Nat. Med. 2007; 13:981-985. [PubMed: 17632528]

125. Wang R, Braughton KR, Kretschmer D, Bach TH, Queck SY, et al. Identification of novel cytolytic peptides as key virulence determinants for community-associated MRSA. Nat. Med. 2007; 13:1510-1514. [PubMed: 17994102] The phenol-soluble modulin family are recognized as key MRSA viruelnce determinants.

126. Wiles KG, Panizzi P, Kroh HK, Bock PE. Skizzle is a novel plasminogen- and plasmin-binding protein from Streptococcus agalactiae that targets proteins of human fibrinolysis to promote plasmin generation. J. Biol. Chem. 2010; 285:21153-21164. [PubMed: 20435890]

127. Winterbourn CC, Kettle AJ. Redox reactions and microbial killing in the neutrophil phagosome. Antioxid. Redox Signal. 2013; 18:642-660. [PubMed: 22881869]

128. Yamaguchi M, Terao Y, Mori Y, Hamada S, Kawabata S. PfbA, a novel plasmin- and fibronectin-binding protein of Streptococcus pneumoniae, contributes to fibronectin-dependent adhesion and antiphagocytosis. J. Biol. Chem. 2008; 283:36272-36279. [PubMed: 18974092]

129. Yesilkaya H, Andisi VF, Andrew PW, Bijlsma JJE. Streptococcus pneumoniae and reactive oxygen species: an unusual approach to living with radicals. Trends Microbiol. 2013; 21:187195. [PubMed: 23415028]

130. Yesilkaya H, Kadioglu A, Gingles N, Alexander JE, Mitchell TJ, Andrew PW. Role of manganese-containing superoxide dismutase in oxidative stress and virulence of Streptococcus pneumoniae. Infect. Immun. 2000; 68:2819-2826. [PubMed: 10768978]

131. Zinkernagel AS, Hruz P, Uchiyama S, von Köckritz-Blickwede M, Schuepbach RA, et al. Importance of toll-like receptor 9 in host defense against M1T1 group A Streptococcus infections. J. Innate Immun. 2012; 4:213-218. [PubMed: 21860217]

132. Zinkernagel AS, Timmer AM, Pence MA, Locke JB, Buchanan JT, et al. The IL-8 protease SpyCEPScpC of group A Streptococcus promotes resistance to neutrophil killing. Cell Host Microbe. 2008; 4:170-178. [PubMed: 18692776]

133. Zysk G, Bejo L, Schneider-Wald BK, Nau R, Heinz H. Induction of necrosis and apoptosis of neutrophil granulocytes by Streptococcus pneumoniae. Clin. Exp. Immunol. 2000; 122:61-66. [PubMed: 11012619] 


\section{SUMMARY POINTS}

1. Gram-positive pathogens have mechanisms to bind host complement inhibitory proteins to prevent activation of the complement system.

2. Gram-positive pathogens either prevent or reorient the binding of opsonins to the bacterial surface to prevent opsonophagocytosis.

3. Though mostly catalase-negative, gram-positive pathogens possess several antioxidant systems that provide protection against ROS and prevent the generation of $\mathrm{HOCl}$.

4. All gram-positive pathogens can modify their peptidoglycan structures to prevent recognition and cleavage by lysozyme, preventing intracellular PRR detection.

5. Gram-positive bacteria modify their surface charge and prevent access to the bacterial membrane to resist the actions of AMPs or to produce proteases to directly degrade AMPs.

6. Gram-positive bacteria escape from NET-mediated killing using DNases.

7. Gram-positive bacteria are capable of either avoiding or dampening immune detection by phagocytic cells.

8. Capsules and toxins of gram-positive bacteria are multifaceted virulence factors that defend the bacteria against multiple arms of innate immunity. 


\section{Role of Pattern-Recognition Receptors in the Recognition of Gram-Positive Pathogens}

PRRs play a crucial role in the recognition of highly conserved pathogen-associated molecular patterns and subsequent activation of innate immune cells. TLRs expressed on the surface of immune cells (TLR1, 2, 4, 6) have proven to serve only minor roles in defense against gram-positive bacteria, which are classically described as extracellular pathogens. Of the extracellular TLRs, only TLR2, which generally recognizes lipoproteins, has the potential to recognize gram-positive bacteria, though there is some debate as to whether LTA specifically is recognized by TLR2 (102). However, TLR2 has been shown to be dispensable in mouse models of infection by gram-positive bacteria $(42,47,68)$. Conversely, bacteria that have been phagocytosed and digested (109) reveal ligands that can be recognized by intracellular PRRs, such as TLR9, which recognizes bacterial DNA, and NOD2, which recognizes muramyldipeptide of PPG $(24,131)$. Activation of these intracellular PRRs leads to the formation and activation of the NLRP3 inflammasome, which activates the cytokine IL-1 $\beta$, which regulates neutrophil recruitment to sites of infection $(31,84)$. Thus, intracellular PRRs are critical mediators of the innate immune response to gram-positive pathogens. 


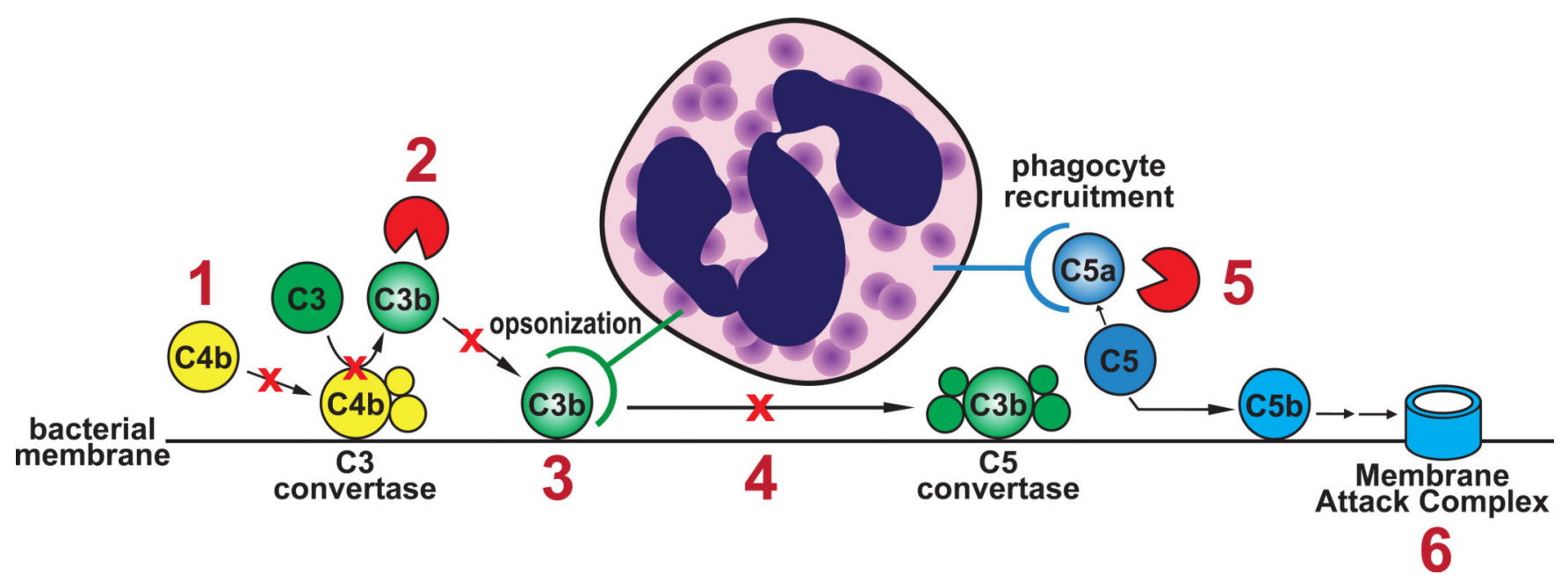

Figure 1.

Inhibition of complement activation and interference with complement effectors by grampositive pathogens. Gram-positive pathogens have multiple strategies to defend against complement activation and function, including (1) preventing the formation and activity of the $\mathrm{C} 3$ convertase, (2) proteasomal degradation of C3b, (3) blocking C3b deposition on bacterial surfaces, (4) preventing formation and activity of the C5 convertase, (5) proteasomal degradation of $\mathrm{C} 5 \mathrm{a}$, and (6) resistance to lysis by the membrane attack complex (MAC). 


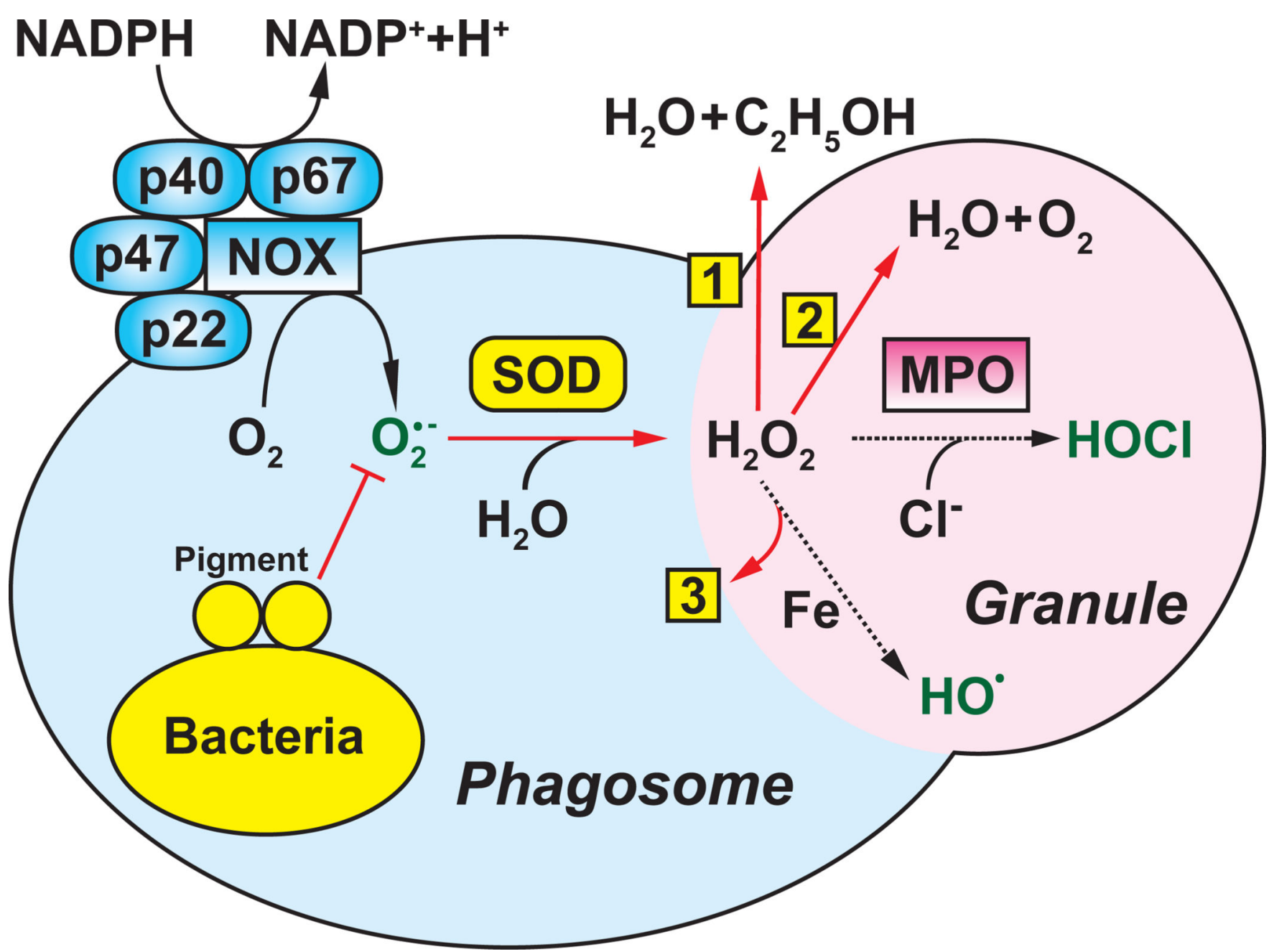

Figure 2.

Gram-positive pathogens interfere with ROS production and function. Engulfment of bacteria triggers NADPH oxidase (NOX)-dependent generation of superoxide. Bacterial superoxide dismutase (SOD) accelerates the generation of hydrogen peroxide from superoxide. Bacteria subsequently neutralize hydrogen peroxide by using enzymes that (1) convert peroxide to alcohol, (2) convert peroxide to molecular oxygen or (3) possess ironcontaining molecules or generate nitric oxide to prevent Fenton chemistry. Depleting hydrogen peroxide prevents formation of highly bactericidal hypochlorite. Gram-positive bacteria additionally have molecules such as pigment, which acts as a molecular shield against superoxide anions. The most bactericidal ROS species are indicated in green. 


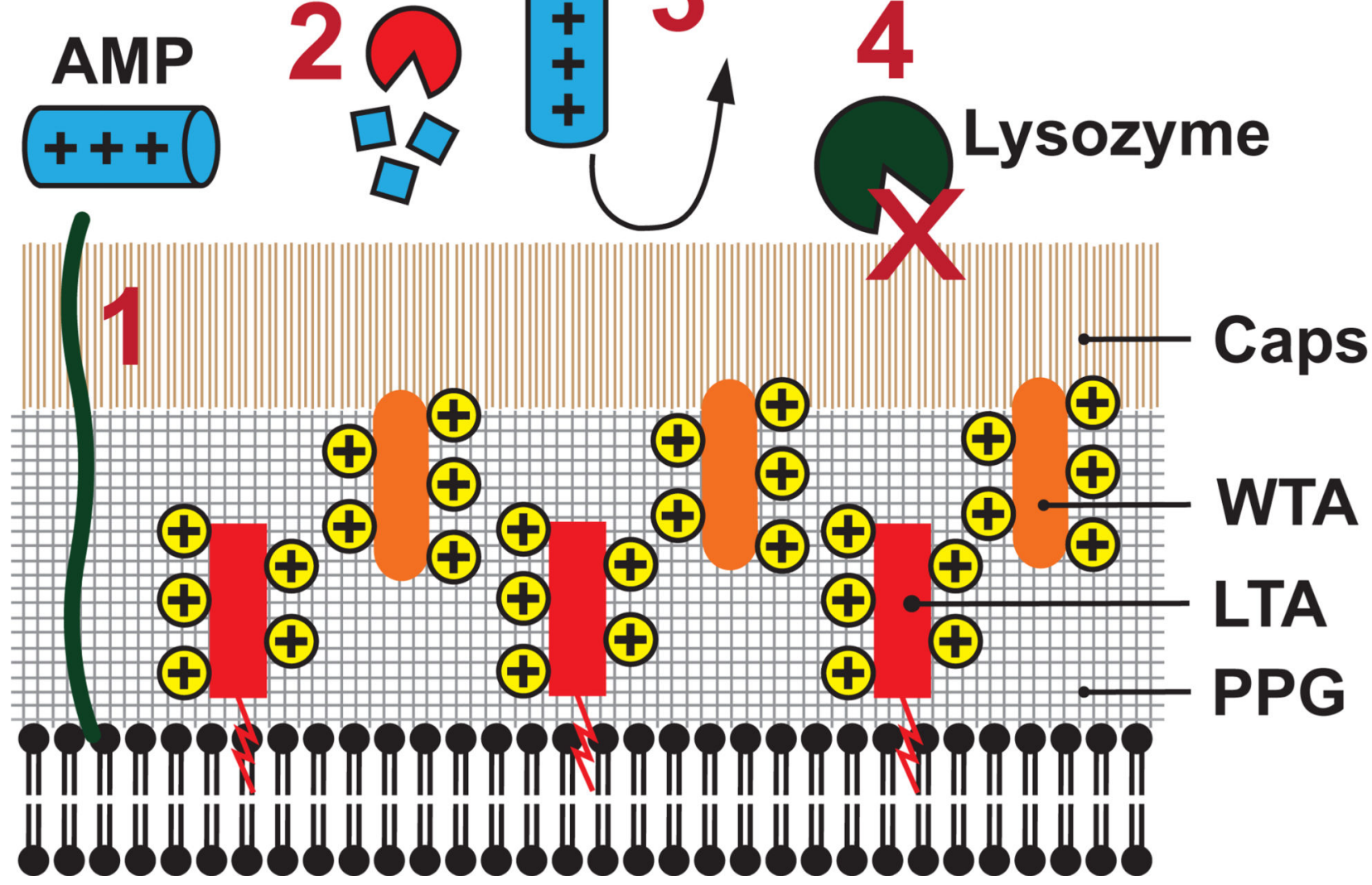

Figure 3.

Gram-positive pathogens physically alter their surface to thwart antimicrobial granule contents. Gram-positive bacteria produce (1) Antimicrobial peptide (AMP) binding molecules or (2) AMP degrading enzymes, which prevent AMP access. The density and altered charge of molecules such as lipoteichoic acid (LTA), wall teichoic acid (WTA) and exopolysaccharide capsule further prevent AMPs from accessing the bacterial membrane (3). Modification of peptidoglycan (PPG) prevents cleavage and degradation by lysozyme (4). 


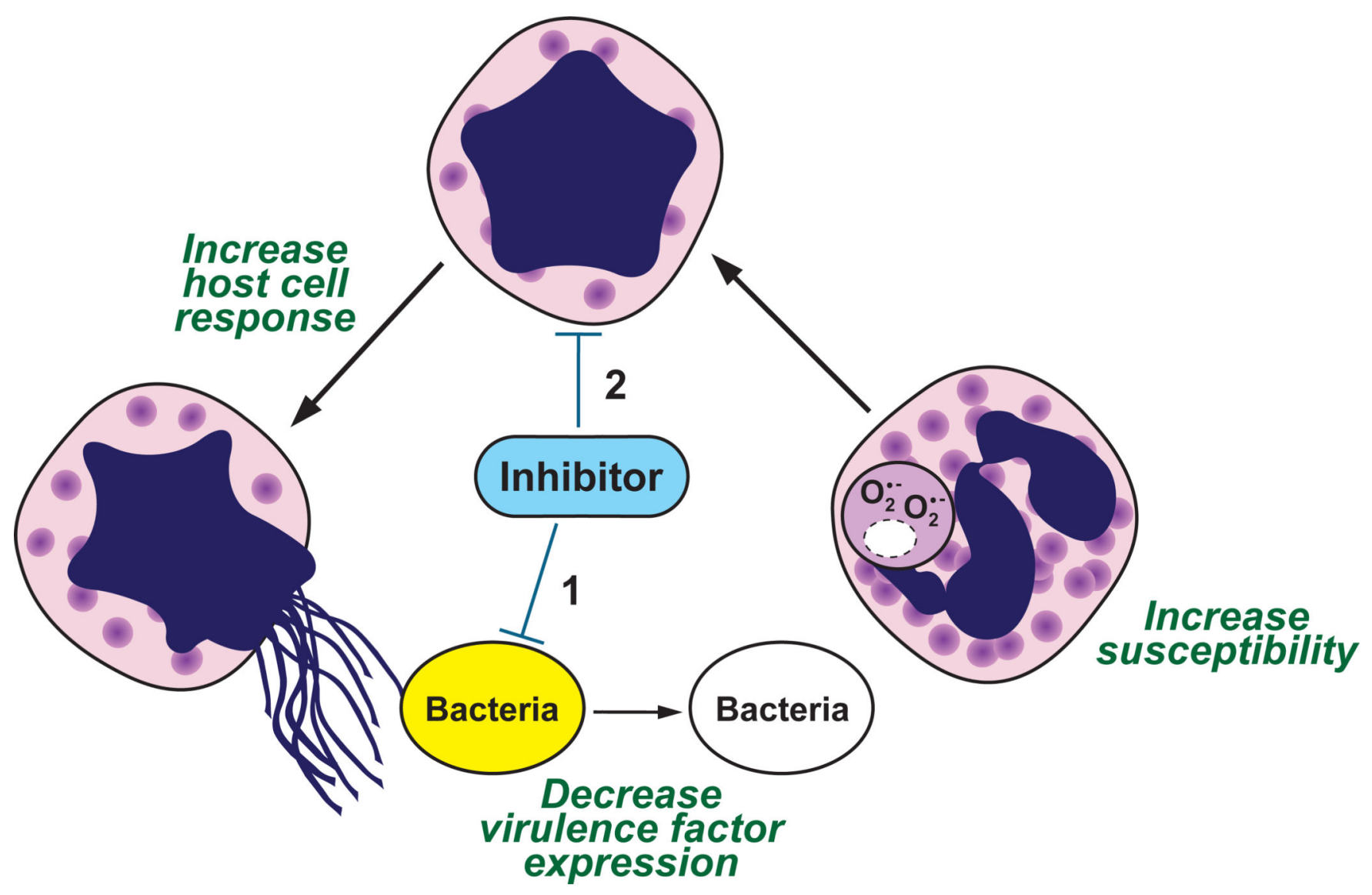

Figure 4.

Dual specificity therapeutic agents that target bacterial virulence factors to increase susceptibility to host cell clearance mechanisms and increase the host cell response could provide a multi-faceted approach to treatment. One such example is a squalene synthesis inhibitor, which blocks staphyloxanthin production (1) while simultaneously enhancing the capacity of neutrophils to produce NETs (2). 